Journal of European Public Policy

\title{
Ideas, Political Power and Public Policy
}

\section{Daniel Béland, Martin B. Carstensen \& Leonard Seabrooke}

To cite this article: Daniel Béland, Martin B. Carstensen \& Leonard Seabrooke (2016) Ideas, Political Power and Public Policy, Journal of European Public Policy, 23:3, 315-317, DOI: 10.1080/13501763.2015.1122163

To link to this article: https://doi.org/10.1080/13501763.2015.1122163

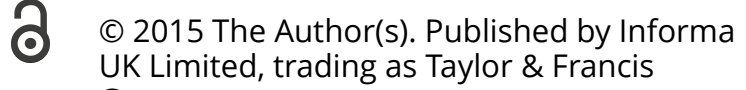
Group

曲 Published online: 23 Dec 2015.

Submit your article to this journal $\pi$

Џ Article views: 2502

Q View related articles $₫$

View Crossmark data $\asymp$

Cᄌ C C 


\title{
Introduction \\ IDEAS, POLITICAL POWER AND PUBLIC POLICY
}

\author{
Daniel Béland, Martin B. Carstensen and \\ Leonard Seabrooke
}

Throughout the last couple of decades, scholars have increasingly emphasized the importance of political ideas in understanding processes of change and stability in politics and public policy. The aim of ideational analysis in policy studies has not just been to theorize the representation or embodiment of ideas and the interactive processes by and through which ideas are generated and communicated. It has also underlined the importance of considering both ideas and discourse in the institutional context within which political actors both 'power' and 'puzzle'. Naturally, the causal 'power of ideas' has been an important subject of study in the ideational tradition, spawning important studies on how ideas and ideologies are institutionalized and how they define the interests of strategic policy actors. The power of ideas has always reigned among the most important issues in ideational analysis. With this in mind, it may come as a surprise that relatively little has been done to more clearly conceptualize the relationship between the concept of political power and the role of ideas in public policy.

The ideational side of power relations (which may be called ideational power) requires further study. At least part of this relative lack of connection to power theory seems attributable to ideational scholars' strong focus on supporting the more general claim that 'ideas matter' as causes, thus carving out a clear position vis-à-vis more traditional interest-oriented approaches. This effort has clearly been fruitful - as seen not least by the growing attention to ideas within policy studies and political science more generally - but the central task of delineating how ideational scholarship can contribute to understandings of power remains.

The present edited collection sets out to do so in two principal ways. First, building on existing ideational scholarship, contributors to this collection take on the task of investigating the relation between ideas and political power to develop clearer understandings of ideational power in policy research. Second, this collection is focused on conceptualizing the relationship between 
political power and ideas. In other words, the contributions combine a strong grounding in ideational analysis with an equally strong commitment to connect with and draw on the approaches to power developed in other traditions of policy studies and political science.

Studying the relationship between policy ideas and power is not only important for ideational scholarship but also relevant for the larger power debate in political science. To be sure, although students of power have acknowledged the central role of perceptions and interpretations for the practice of power in politics - perhaps most famously in Steven Lukes's third face of power - the power debate has too often depended on scholars from outside political science and policy studies to further conceptualize the relationship between power and ideas. Michel Foucault's work is noteworthy in this regard. This literature has been helpful in promoting a stronger focus on the relation between ideas and power, but there are a number of methodological and epistemological problems involved in 'transposing' these insights into policy studies. This collection seeks to develop an approach to ideational power more clearly wedded to a political science tradition.

Following a conceptual analysis by Martin B. Carstensen and Vivien Schmidt, the contributions featured in the present collection all address the relationship between ideas and political power. They study this relationship across a wide range of issues and topics, which range from coalition building and ideational explanation to neoliberalism and the role of professionals and of central bankers in public policy. The contributions relate power to ideas by delineating mechanisms through which they interact. For some this follows the 'power in', 'power over' and 'power through' ideas framework advocated by Carstensen and Schmidt, which focuses the scholars to not only consider interests as a form of idea - a common assertion in ideational analysis but also the institutional environments, collective and personal tactics, and resources drawn upon to express ideas as interests. For other contributors the focus is more on mapping who is promoting which ideas and the institutions and networks they draw upon. Either way, the contributions theorize the relationship between ideas, power and public policy. The collection ends with a short essay by Mark Blyth. Taken together, these contributions make three central contributions. First, by moving the concept of power to the centre of ideational policy analysis and by developing a specific category of ideational power comparable to other forms of power, it brings greater conceptual clarity to the role of ideas in public policy. Second, it shows the empirical relevance of this broad approach to power by employing it in a substantive analysis of a diverse set of policy areas. Finally, to further the development of the study of policy ideas, this collection connects two literatures that up until now have too often lived separate lives, namely ideational analysis and the power debate of public policy and political science. Taken together, this collection aims to refocus the study of ideas in politics to address in clearer conceptual terms how ideas come to impact policy-making. 
The contributors to the collection all participated in a two-day workshop held at the Copenhagen Business School in June 2014 and funded by the European Commission FP7 grant 'GREEN - Global Reordering: Evolution through European Networks' (\#266809-GR:EEN). Further work by Carstensen and Seabrooke, and some contributors to this collection, has been supported by the Horizon 2020-funded project 'European Legitimacy in Governing through Hard Times: The role of European Networks' (\#649456ENLIGHTEN). Thanks are due to the workshop participants, including Cornel Ban, Joelle Dumouchel, Juliet Johnson and Ben Rosamond. We also wish to gratefully acknowledge the hard work of the reviewers, as well as the useful input and advice of the editors of the Journal of European Public Policy. 